Nevada

Environmental

Restoration

Project

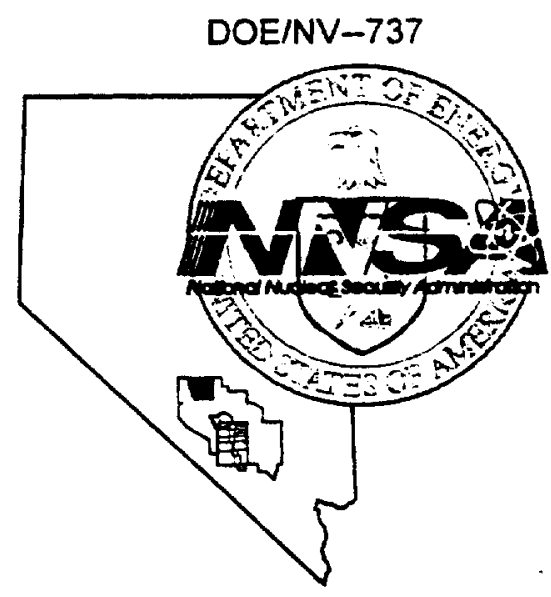

Post-Closure Inspection Report for Corrective Action Unit 426:

Cactus Spring Waste Trenches

Tonopah Test Range, Nevada

Calendar Year 2000

Controlled Copy No.:

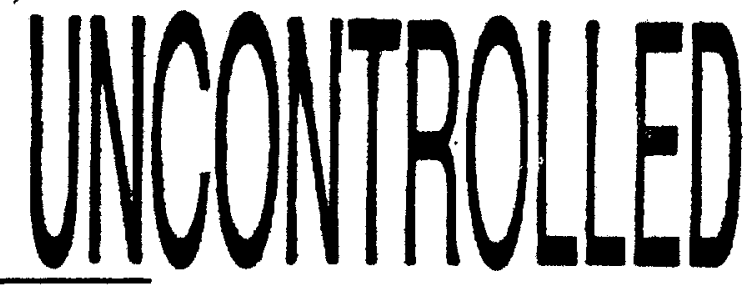

Revision: 0

June 2001

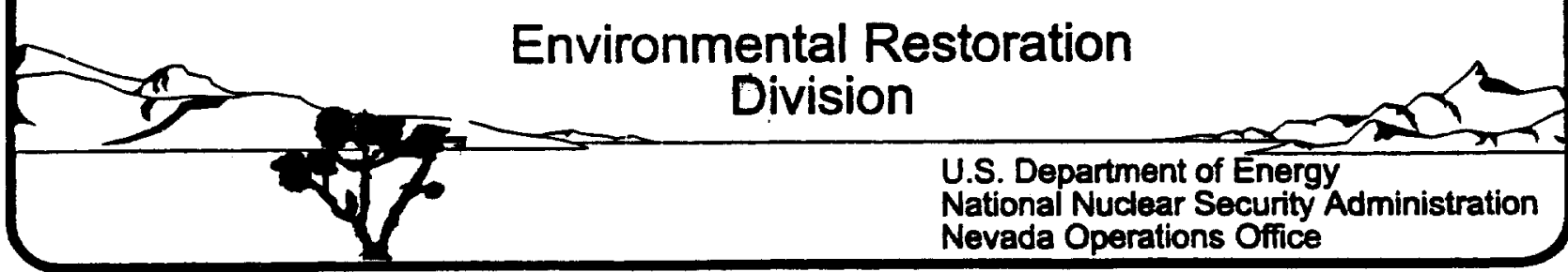




\section{DISCLAIMER STATEMENT}

Reference herein to any specific commercial product, process, or service by trade name, trademark, manufacture, or otherwise, does not necessarily constitute or imply its endorsement, recommendation, or favoring by the U.S. Government or any agency thereof or its contractors or subcontractors.

\section{AVAILABILITY STATEMENT}

Available for sale to the public from-

U.S. Departmen of Commerce

National Technical Information Service

5285 Port Royal Road

Springfield, VA 22161-0002

Telephone: 800.553 .6847

Fax: 703.605.6900

E-mail: orders@ntis.fedworld.gov

Online ordering http://www.ntis.gov/ordering.htm

Available electronically at http://www.doe.gov/bridge

Available for a processing fee to U.S. Department of Energy and its contractors, in paper, fromU.S. Department of Energy

Office of Scientific and Technical Information

P.O. Box 62

Oak Ridge, TN 37831-0062

Telephone: 865.576.8401

Fax: 865.576.5728

E-mail: reports@adonis.osti.gov 


\title{
POST-CLOSURE INSPECTION REPORT FOR CORRECTIVE ACTION UNIT 426: CACTUS SPRING WASTE TRENCHES TONOPAH TEST RANGE, NEVADA CALENDAR YEAR 2000
}

\author{
Prepared for \\ U. S. Department of Energy \\ National Nuclear Security Administration \\ Nevada Operations Office \\ Work Performed Under Contract No. \\ DE-AC08-96NV11718
}

Controlled Copy No.:

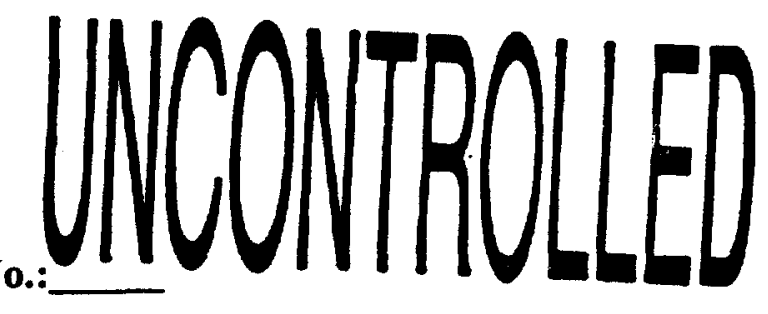

Revision: 0

June 2001 


\section{THIS PAGE INTENTIONALLY LEFT BLANK}

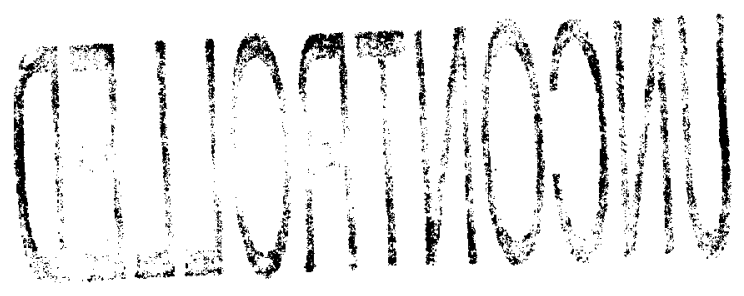




\section{POST-CLOSURE INSPECTION REPORT FOR CORRECTIVE ACTION UNIT 426: CACTUS SPRING WASTE TRENCHES TONOPAH TEST RANGE, NEVADA CALENDAR YEAR 2000}
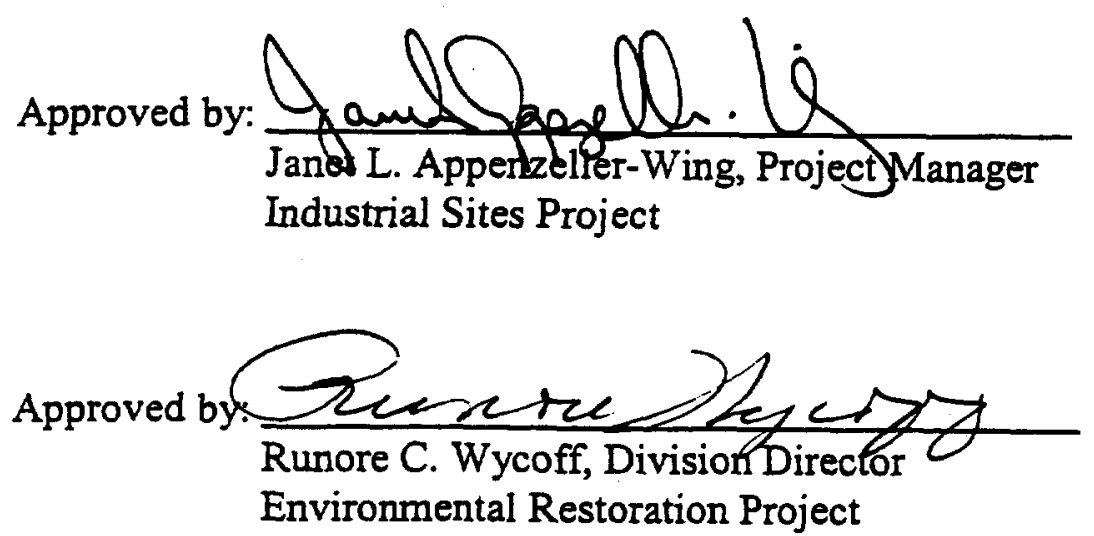

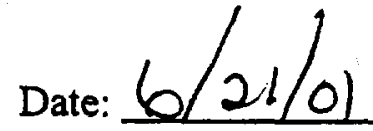

Date: $6 / 21 / 61$ 


\section{TABLE OF CONTENTS}

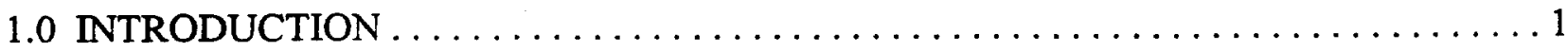

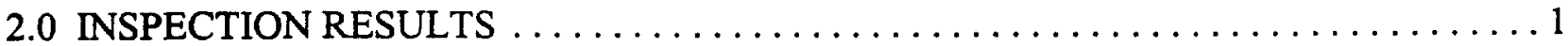

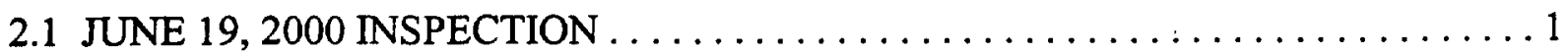

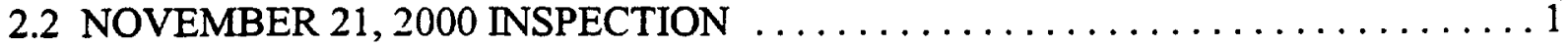

3.0 VEGETATIVE MONITORING $\ldots \ldots \ldots \ldots \ldots \ldots \ldots \ldots \ldots \ldots \ldots \ldots \ldots \ldots$

4.0 CONCLUSIONS AND RECOMMENDATIONS $\ldots \ldots \ldots \ldots \ldots \ldots \ldots \ldots \ldots \ldots$

\section{FIGURES}

FIGURE 1 - CACTUS SPRING WASTE TRENCHES CAU 426 LOCATION MAP . . . . . 2

\section{TABLES}

TABLE 1 - SUMMARY OF VEGETATIVE MONITORING RESULTS FOR MAY 2000 . . . 5

\section{ATTACHMENTS}

ATTACHMENT A - INSPECTION CHECKLISTS

ATTACHMENT B - FIELD NOTES

ATTACHMENT C - PHOTOGRAPH LOG AND PHOTOGRAPHS

\section{DRAFT DISTRIBUTION LIST}


$\mathbf{a}$

-

-

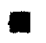

a

-

-

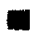

THIS PAGE INTENTIONALLY LEFT BLANK

u

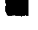

a

0

a 


\subsection{INTRODUCTION}

Post-closure monitoring requirements for the Cactus Spring Waste Trenches (Corrective Action Unit [CAU] 426) (Figure 1) are described in Closure Report for Corrective Action Unit 426. Cactus Spring Waste Trenches, Tonopah Test Range, Nevada, report number DOE/NV--226. The Closure Report (CR) was submitted to the Nevada Division of Environmental Protection (NDEP) on August 14, 1998. Permeability results of soils adjacent to the engineered cover and a request for closure of CAU 404 were transmitted to the NDEP on April 29, 1999. The CR (containing the Post-Closure Monitoring Plan) was approved by the NDEP on May 13, 1999.

Post-closure monitoring at CAU 426 consists of the following:

- Site inspections done twice a year to evaluate the condition of the unit.

- Verification that the site is secure.

- Notice of any subsidence or deficiencies that may compromise the integrity of the unit.

- Remedy of any deficiencies within 90 days of discovery.

- Preparation and submittal of an annual report.

Site inspections were conducted on June 19, 2000, and November 21, 2000. All inspections were made after NDEP approval of the CR, and were conducted in accordance with the Post-Closure Monitoring Plan in the NDEP-approved CR.

This report includes copies of the inspection checklists, photographs, recommendations, and conclusions. The Post-Closure Inspection Checklists are found in Attachment A, a copy of the field notes is found in Attachment $B$, and copies of the inspection photographs are found in Attachment C.

\subsection{INSPECTION RESULTS}

\subsection{June 19, 2000 Inspection}

The first inspection was completed on June 19,2000. Rabbit scat and small mammal burrows were observed on the site. Small mammal burrows were present along the toe of the south and east cover side slopes allowing access to the cover area by small mammals. Burrows were filled with soil and the fence re-buried. The burrows have not effected the integrity of the cover. The vegetation present on the cover and in the staging area inside the fence appears sparse but healthy. There is no evidence of erosion of the cover or staging area. Two signs were reattached to the fence using hog rings. No further maintenance or repairs are recommended.

\subsection{November 21, 2000 Inspection}

The fourth inspection was completed on November 21, 2000. Small and shallow 
Date: June 21, 2001
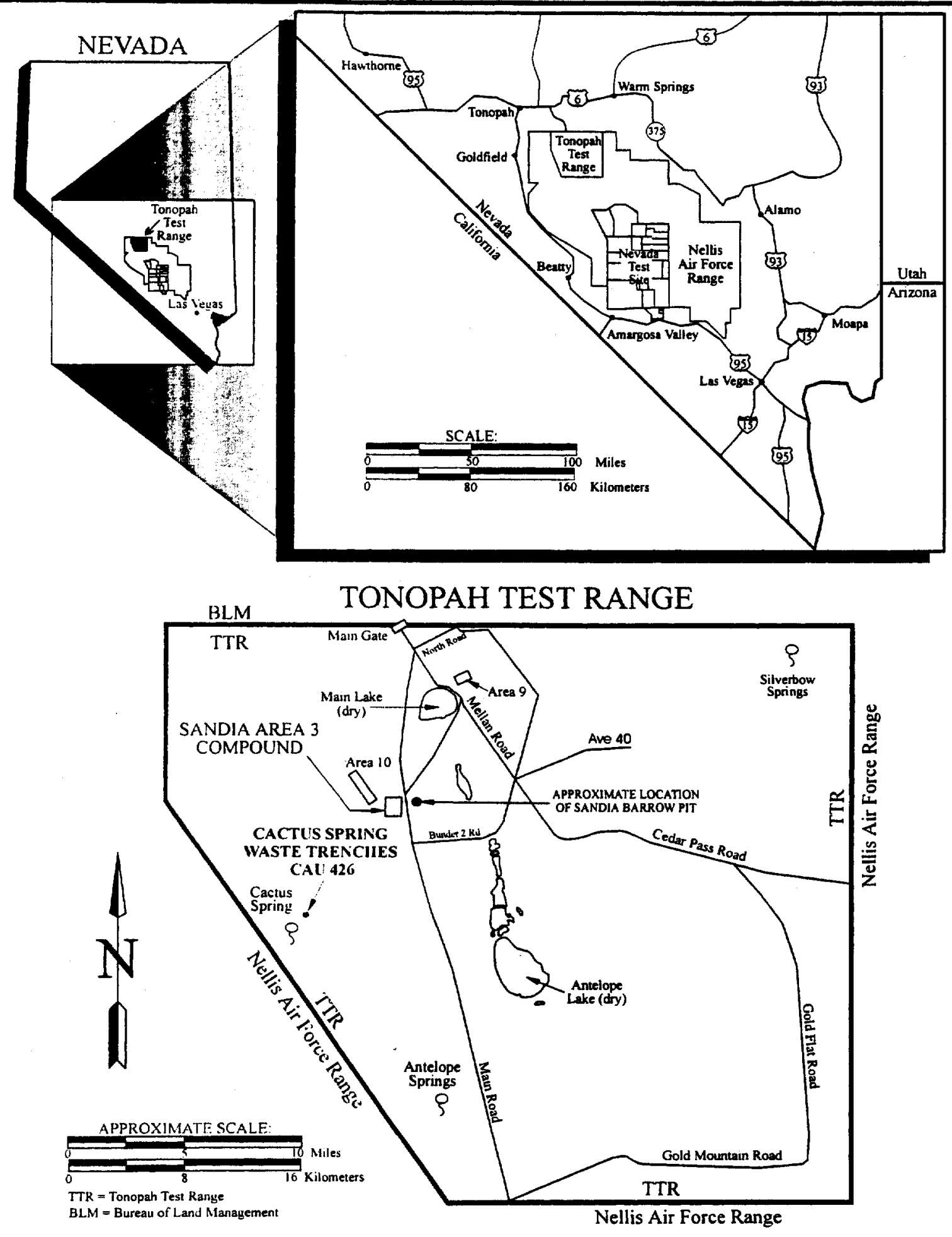

FIGURE 1

CACTUS SPRING WASTE TRENCHES

CAU 426 LOCATION MAP 
burrowing/scratchings (approximately 5 centimeters [cm] [2 inches [in.]) to $16 \mathrm{~cm}$ (6 in) in diameter and depth) were observed along the fence line, not on the cover. The vegetation on the cover and staging area was healthy with a good variety of shrubs and grasses present. The cover was observed to be stable with no noticeable erosion, settling, or cracking. Evaluation of the cover area plant diversity and density is recommended for the fifth year after revegetation (2002) to determine if the site has been successfully reclaimed or if remediation work is necessary. No further maintenance or repairs are recommended at this time.

\subsection{VEGETATIVE MONITORING}

In addition to the twice annual inspections by Bechtel Nevada Environmental Restoration personnel, the Post-Closure Monitoring Plan contained in the approved CR, proposed vegetative monitoring in the first, third, and fifth year after revegetation was completed. Vegetative monitoring for the first year after revegetation was performed as proposed in the Post-Closure Monitoring Plan. The vegetative monitoring conducted during the site inspections on May 24, 2000 , and November 14, 2000 fulfill the proposed monitoring in the third year after completion of site revegetation. Germination, wildlife usage, and erosion condition of the soil were observed. Site plant densities were determined by placing a quadrat ( 1 meter by 1 meter square frame) at randomly selected locations within the fenced area and counting the number and type of plant species present within the quadrat. A total of 45 randomly selected locations were surveyed in May; 15 on the cover area, and 30 on the staging area (inside the fence but off of the cover). The number and type of plants within each randomly placed quadrat was recorded on field data sheets. Table 1 presents the summarized data for the May 24 site visit. Wildlife usage of the site was determined by recording the presence of animal scat within the quadrats. The erosion condition of the soil over the site in general was determined using an erosion condition classification.

Ten of the 12 seeded species were observed at the site. Eight seeded species were observed on the cover, with approximately five seeded species present per square meter (1.2 square yards). In the staging area, 10 of the 12 seeded species were observed, with approximately eight seeded species present per square meter (1.2 square yards). In addition, less than one non-seeded plant was observed per square meter on the cover, and approximately 14 non-seeded plants per square meter were observed in the staging area. (Non-seeded plants include two invasive nuisance species commonly known as halogeton and wheat grass.) As the native species become better established, these invasive species will decline in numbers. Straw mulch from the revegetation activities is still present on both the cover and staging area but covers five percent or less of the areas. No evidence of grazing by rabbits or other species was observed within the fence. However, rabbit scat was observed in all of the quadrats sampled in the staging area, and in approximately one third of the quadrats sampled on the cover. Minor scratching/burrowing was observed in the vegetative portion of the cover. No signs of erosion, settling, or cracking of the cover or of the staging area were observed. The overall condition of the vegetative cover is excellent with a good diversity of native shrubs and grasses established. In addition, many species were observed to be flowering and setting seed. 


\subsection{CONCLUSIONS AND RECOMMENDATIONS}

No evidence of erosion was noted in any of the inspections, indicating that the overland runoff is being properly diverted around the cover. Rabbits have burrowed under the fence in several areas but the presence of burrows in the area do not appear to have adversely effected the cover. The density of seedlings was less than anticipated but a good diversity of native plant species has established in the area and is producing seed. The overall condition of the vegetative cover is excellent.

Monitoring of the vegetation is recommended following the growing season (May/June) in the fifth year after revegetation (2002) as proposed in the CR. Modifications/repairs to the cover or a change in the inspection frequency are not recommended as a result of the observations conducted. 
TABLE 1 - SUMMARY OF VEGETATIVE MONITORING RESULTS FOR MAY 2000

\begin{tabular}{|c|c|c|c|c|c|}
\hline $\begin{array}{c}\text { LIFE } \\
\text { FORM }\end{array}$ & GENUS & SPECIES & COMMON NAME & \multicolumn{2}{|c|}{$\begin{array}{l}\text { PLANT DENSITY } \\
\quad\left(\text { Plants } / \mathbf{m}^{2}\right) \\
\text { Cover Inside Fence }\end{array}$} \\
\hline Shrub & Artemisia & nova & Black sagebrush & 0 & 0 \\
\hline Shrub & Atriplex & $\begin{array}{l}\text { canescens var. } \\
\text { Canescens }\end{array}$ & Fourwing saltbrush & 0 & 0.1 \\
\hline Shrub & Atriplex & confertfolia & Shadscale saltbrush & 0 & 0.1 \\
\hline Shrub & Chrysothamnus & viscidiflorus & Low rabbitbrush & 0.1 & 0.1 \\
\hline Shrub & Ephedra & nevadensis & Nevada jointfir & 1.0 & 0.3 \\
\hline Shrub & Ericameria & nauseosus & Rubber rabbitbrush & 0.1 & 0.1 \\
\hline Shrub & $\begin{array}{l}\text { Kraschenin- } \\
\text { nikovia } \\
\text { (Ceratoides) }\end{array}$ & lanata & Winterfat & 0.1 & 0.03 \\
\hline Shrub & Sarcobatus & vermiculatus & Black greasewood & 0.1 & 0.03 \\
\hline Grass & $\begin{array}{l}\text { Achnatherum } \\
\text { (Oryzposis) }\end{array}$ & hymenoides & Indian ricegrass & 1.3 & 1.4 \\
\hline Grass & $\begin{array}{l}\text { Elymus } \\
\text { (Sitanion) }\end{array}$ & $\begin{array}{l}\text { elymoides ssp. } \\
\text { elymoides }\end{array}$ & Bottlebrush squirreltail & 1.0 & 5.2 \\
\hline Grass & $\begin{array}{l}\text { Pleuraphis } \\
\text { (Hilaria) }\end{array}$ & jamesii & Galleta grass & 1.4 & 0.2 \\
\hline Forb & Sphaeralcea & ambigus & Apricot globemallow & 0 & 0 \\
\hline \multicolumn{4}{|r|}{ TOTAL SEEDED } & 5.1 & 7.56 \\
\hline Forbs & Halogeton & glomeratus & Halogeton & 0.1 & 16.8 \\
\hline Grasses & Triticum & aestivum & Wheat & 0 & 0.9 \\
\hline \multicolumn{4}{|r|}{ TOTAL NON-SEEDED } & 0.1 & 17.7 \\
\hline \multicolumn{4}{|r|}{ TOTAL Plants/m² } & 5.2 & 25.26 \\
\hline \multicolumn{4}{|r|}{$\%$ MULCH } & $3.3 \%$ & $5.0 \%$ \\
\hline \multicolumn{4}{|r|}{$\%$ PLOTS w/ SCAT } & $27 \%$ & $100 \%$ \\
\hline
\end{tabular}


a

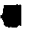

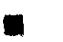

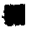

a

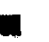

THIS PAGE INTENTIONALLY LEFT BLANK

a

a 


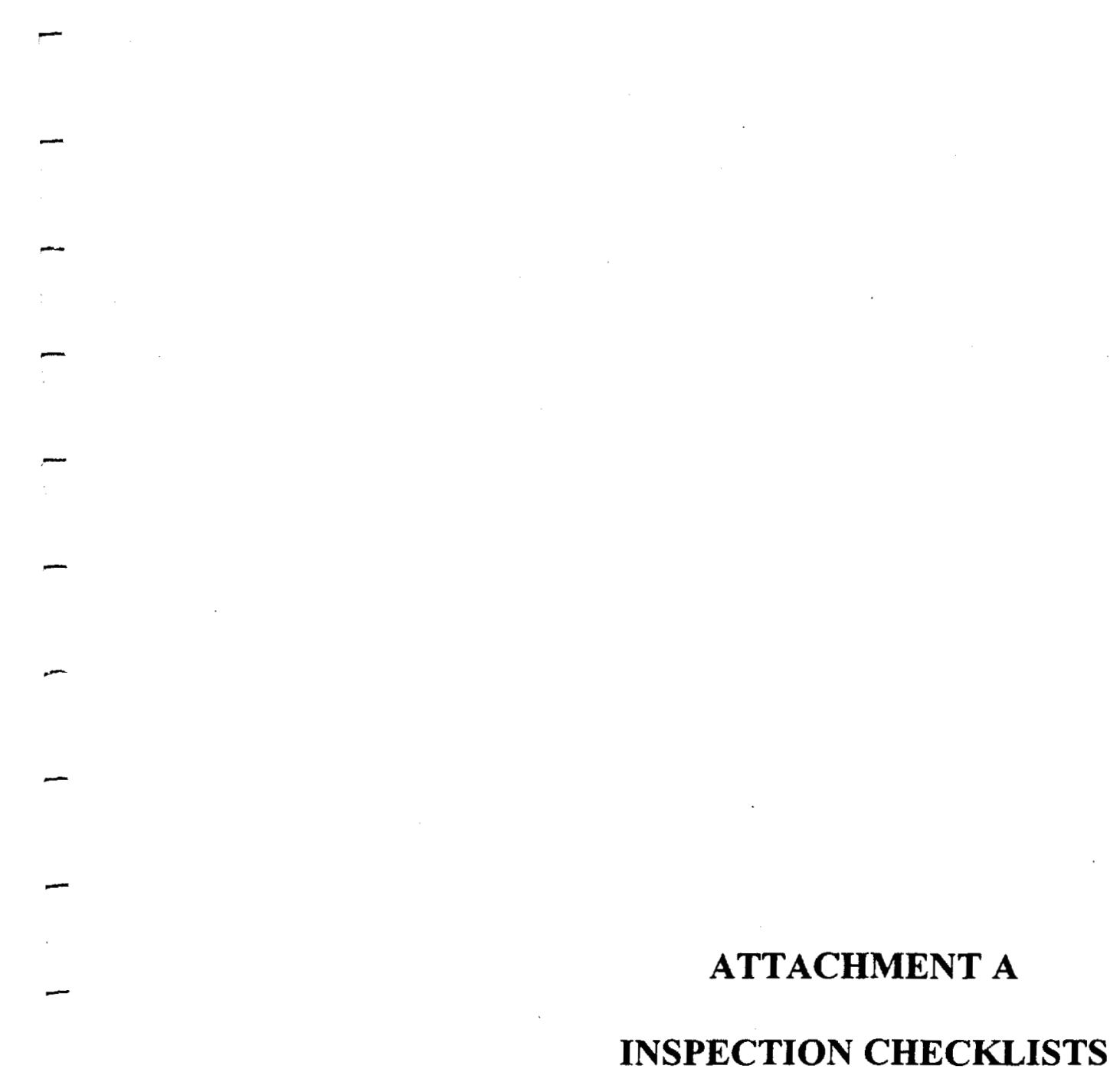


$\square$

-

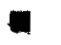

-

a

THIS PAGE INTENTIONALLY LEFT BLANK

-

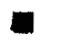

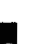




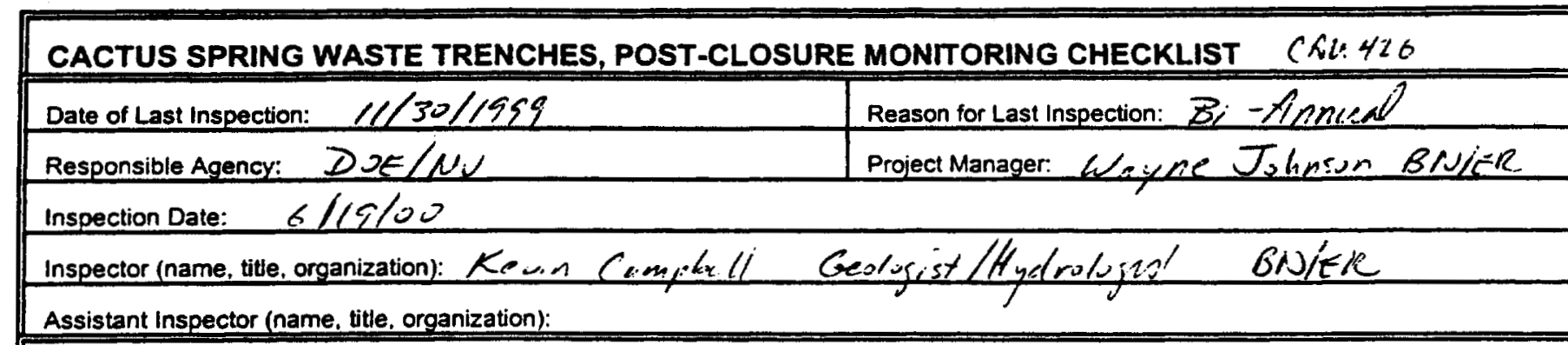

A. GENERAL INSTRUCTIONS

1. All checklist items must be completed and detailed comments made to document the results of the site inspection. The completed checklist is part of the field record of the inspection. Additional pages should be used as necessary to ensure that a complete record is made. Attach the additional pages and number all pages upon completion of the inspection.

3. Any checklist line item marked by an inspector in a SHADED BOX, must be fully explained or an appropriate reference to previous reports provided. The purpose of this requirement is to provide a written explanation of inspector observations and the inspector's rationale for conclusions and recommendations. Explanations are to be placed on additional attachments and cross-referenced appropriately. Explanations, in addition to narrative, will take the form of sketches, measurements, annotated site maps.

4. The site inspection is a walking inspection of the entire site including the perimeter and sufficient transects to be able to inspect the entire surface and all features specifically described in this checklist.

5. A standard set of color $35 \mathrm{~mm}$ photographs (or equivalent) is required. In addition, all anomalous features or new features (such as changes in adjacent area land use) are to be photographed. A photo log entry will be made for each photograph taken.

6. This unit will be inspected biannually with formal reporting to the Nevada Division of Environmental Protection to be done annually. The annual report will include an executive summary, this inspection checklist with field notes and photo log attached, and recommendations and conclusions.

B. PREPARATION (To be completed prior to site visit)

1. Site as-built plans and site base map reviewed.

2. Previous inspection reports reviewed.

a. Were anomalies or trends detected on previous inspections?

b. Was maintenance performed?

3. Site maintenance and repair records reviewed.

a. Has site repair resulted in a change from as-built conditions?

b. Are revised as-builts available that reflect repair changes?

C. SITE INSPECTION (To be completed during inspection)

\begin{tabular}{l|l|l|l}
\cline { 3 - 4 } & & $\sim$ & $N / A$ \\
\hline & YES & NO & EXPLANATION \\
\hline
\end{tabular}

1. Adjacent off-site features within watershed areas.

a. Have there been any changes in use of adjacent area?

b. Are there any new roads or trails?

c. Has there been a change in the position of nearby washes?

d. Has there been lateral excursion or erosion/deposition of nearby washes?

e. Are there new drainage channels?

f. Change in surrounding vegetation?

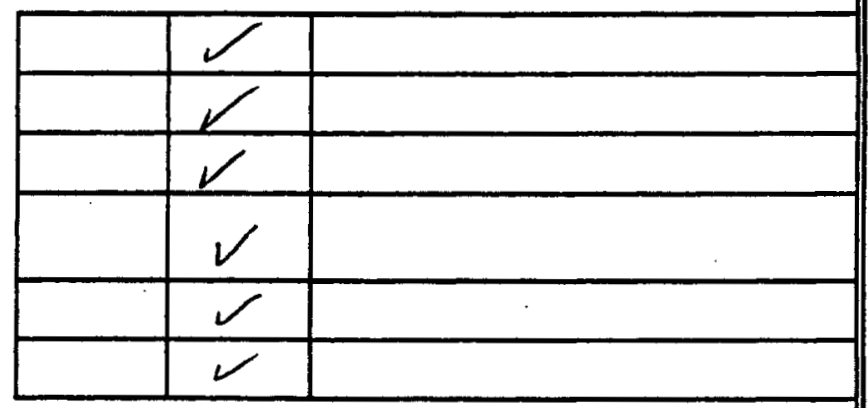

2. Security fence, signs.

a. Displacement of fences, site markers, boundary markers, or monuments?

b. Have any signs been damaged or removed? (Number of signs replaced: ___ (t)

c. Were gates locked?

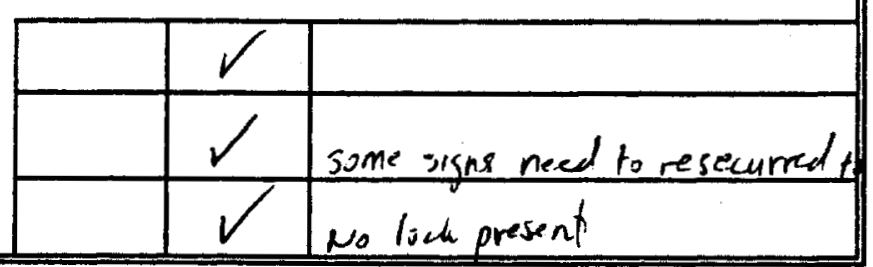




\section{CACTUS SPRING WASTE TRENCHES, POST-CLOSURE MONITORING CHECKLIST}

3. Waste Unit cover.
a. Is there evidence of settling?
b. Is there cracking?
c. Is there evidence of erosion around the cap (wind or water)?
d. Is there evidence of animal burrowing?
e. Have the site markers been disturbed by man or natural processes?
f. Do natural processes threaten to integrity of any cover or site marker?
g. Other?

\begin{tabular}{|c|c|c|}
\hline YES & NO & EXPLANATION \\
\hline & $\checkmark$ & \\
\hline & $\checkmark$ & \\
\hline & $\nu$ & \\
\hline$\swarrow$ & & few hurrasese SE toc at cap \\
\hline & $\swarrow$ & \\
\hline & $\checkmark$ & \\
\hline & & \\
\hline
\end{tabular}

4. Vegetative cover.
a. Is perimeter fence or mesh fencing damaged?
b. Is there evidence of horses or rabbits on site?
c. Is organic mulch adequate to prevent erosion?
d. Are weedy annual plants present? If yes, are they a problem?
e. Are seeded plant species found on site?
f. Is there evidence of plant mortality?

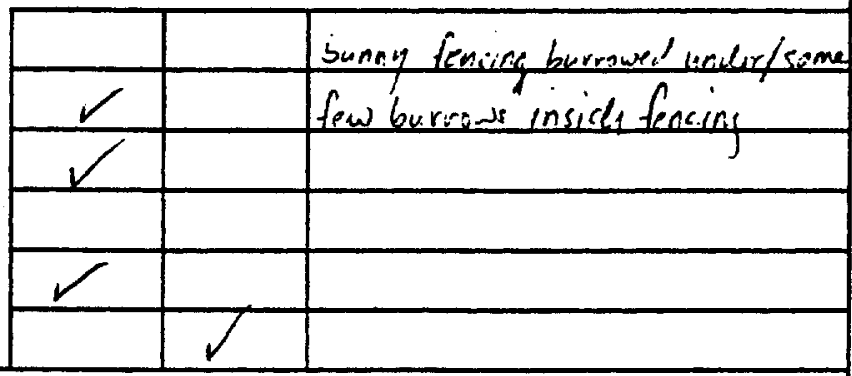

5. Photo Documentation
a. Has a photo log been prepared?
c. Number of photos exposed ( 5 )

\section{FIELD CONCLUSIONS}

1. Is there an imminent hazard to the integrity of the unit? (Immediate report required)

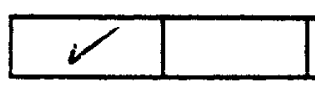

Person/Agency to whom report made:

\section{Are more frequent inspections required?}

3. Are existing maintenance/repair actions satisfactory?

4. Is other maintenance/repair necessary?

5. Is current status/condition of vegetative cover satisfactory?

6. Rationale for field conclusions:

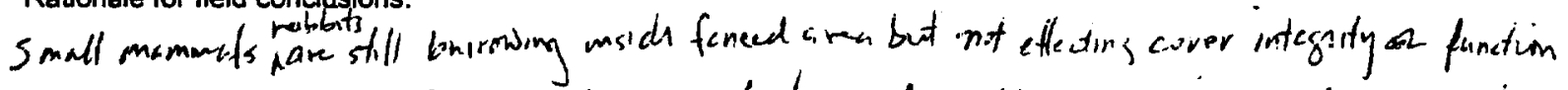

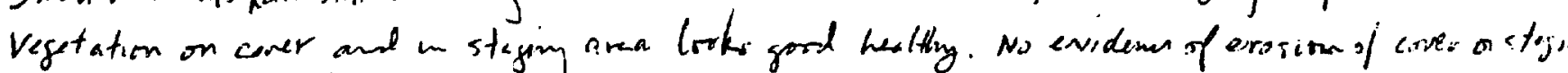

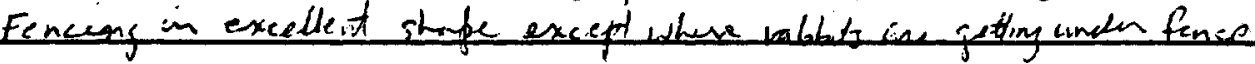

\section{E. CERTIFICATION}

I have conducted an inspection of the Cactus Spring Waste Trenches, CAU 426, at the TTR in accordance with the Post-Closure Monitoring Plan (see Closure Report) as recorded on this checklist, attached sheets, field notes, photo logs, and photographs.

Chief Inspector's Signature:

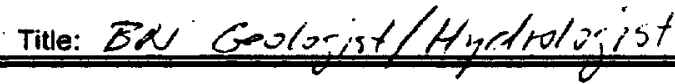
Printed Name: Kevin $\&$ Climploll 
CACTUS SPRING WASTE TRENCHES, POST-CLOSURE MONITORING CHECKLIST

\begin{tabular}{|c|c|}
\hline Date of Last Inspection: $6 / 19 / 00$ & Reason for Last Inspection: $\beta_{1}-A_{n}$ used insecotin \\
\hline Responsible Agency: $\quad D O E / N V$ & Project Manager: i). Johnson BN/ER \\
\hline Inspection Date: $1 / 1 / 21 / 00$ & (1) \\
\hline
\end{tabular}

A. GENERAL INSTRUCTIONS

1. All checklist items must be completed and detailed comments made to document the results of the site inspection. The completed checklist is part of the field record of the inspection. Additional pages should be used as necessary to ensure that a complete record is made. Attach the additional pages and number all pages upon completion of the inspection.

3. Any checklist line item marked by an inspector in a SHADED BOX, must be fully explained or an appropriate reference to previous reports provided. The purpose of this requirement is to provide a written explanation of inspector observations and the inspector's rationale for conclusions and recommendations. Explanations are to be placed on additional attachments and cross-referenced appropriately. Explanations, in addition to narrative, will take the form of sketches, measurements, annotated site maps.

4. The site inspection is a walking inspection of the entire site including the perimeter and sufficient transects to be able to inspect the entire surface and all features specifically described in this checklist.

5. A standard set of color $35 \mathrm{~mm}$ photographs (or equivalent) is required. In addition, all anomalous features or new features (such as changes in adjacent area land use) are to be photographed. A photo log entry will be made for each photograph taken.

6. This unit will be inspected biannually with formal reporting to the Nevada Division of Environmental Protection to be done annualiy. The annual report will include an executive summary, this inspection checklist with field notes and photo log attached, and recommendations and conclusions.

B. PREPARATION (To be completed prior to site visit)

1. Site as-built plans and site base map reviewed.

2. Previous inspection reports reviewed.

a. Were anomalies or trends detected on previous inspections?

b. Was maintenance performed?

3. Site maintenance and repair records reviewed.

a. Has site repair resulted in a change from as-built conditions?

b. Are revised as-builts available that reflect repair changes?

C. SITE INSPECTION (TO be completed during inspection)

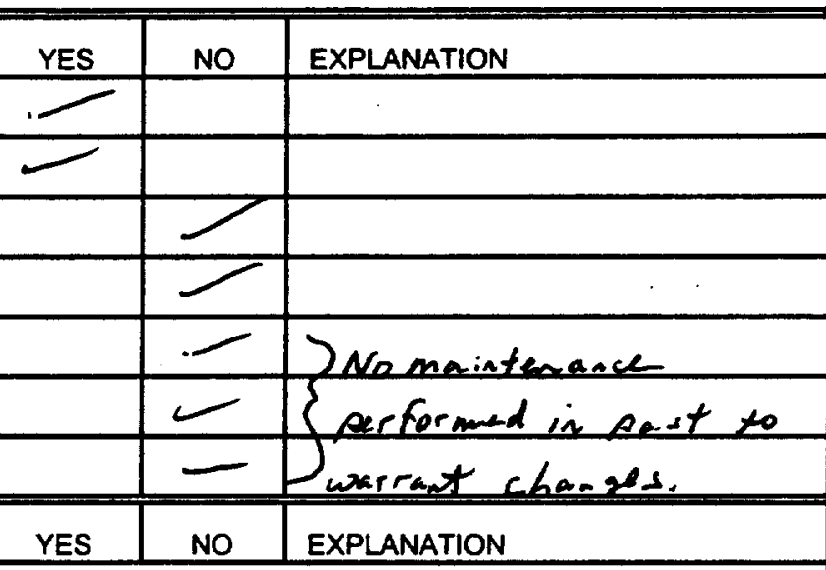

1. Adjacent off-site features within watershed areas.

a. Have there been any changes in use of adjacent area?

b. Are there any new roads or trails?

c. Has there been a change in the position of nearby washes?

d. Has there been lateral excursion or erosion/deposition of nearby washes?

e. Are there new drainage channels?

f. Change in surrounding vegetation?

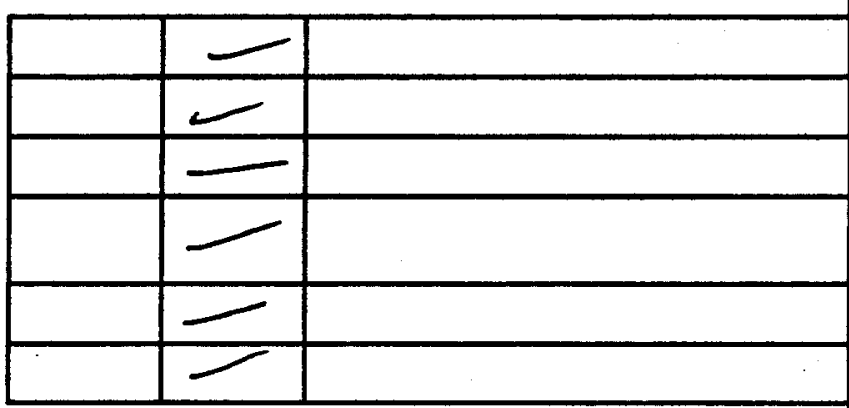

2. Security fence, signs.

a. Displacement of fences, site markers, boundary markers, or monuments?

b. Have any signs been damaged ofremoved? (Number of signs replaced: 8

c. Were gates locked?

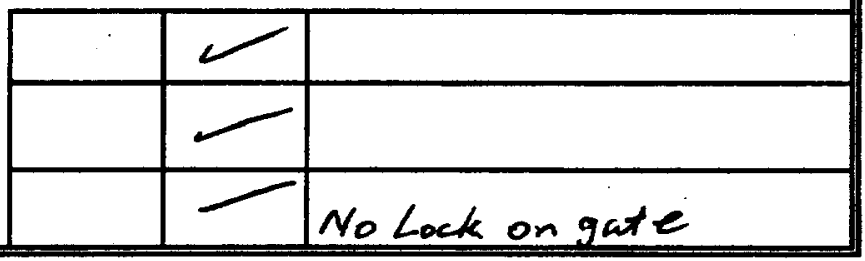




\section{CACTUS SPRING WASTE TRENCHES, POST-CLOSURE MONITORING CHECKLIST}

3. Waste Unit cover.

a. Is there evidence of settling?

b. Is there cracking?

c. Is there evidence of erosion around the cap (wind or water)?

d. Is there evidence of animal burrowing?

e. Have the site markers been disturbed by man or natural processes?

f. Do natural processes threaten to integrity of any cover or site marker?

g. Other?

\begin{tabular}{|l|l|l|}
\hline YES & NO & EXPLANATION \\
\hline & 2 & \\
\hline & 2 & \\
\hline & 2 & Only w/ong Foncelome, not \\
\hline & & \\
\hline & & \\
\hline & & \\
\hline & & \\
\hline
\end{tabular}

4. Vegetative cover.
a. Is perimeter fence or mesh fencing damaged?
b. Is there evidence of horses or rabbits on site?
c. Is organic mulch adequate to prevent erosion?
d. Are weedy annual plants present? If yes, are they a problem?
e. Are seeded plant species found on site?
f. Is there evidence of plant mortality?

\begin{tabular}{|l|l|l|}
\hline & - & \\
\hline & & $\begin{array}{l}\text { Pab6it scratehing under } \\
\text { mash feace }\end{array}$ \\
\hline & & \\
\hline & & \\
\hline & & \\
\hline & & \\
\hline
\end{tabular}

5. Photo Documentation

a. Has a photo log been prepared?

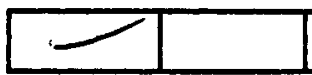

c. Number of photos exposed $(5)$

\section{FIELD CONCLUSIONS}

1. Is there an imminent hazard to the integrity of the unit? (Immediate report required)

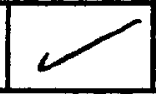

Person/Agency to whom report made:

2. Are more frequent inspections required?

3. Are existing maintenance/repair actions satisfactory?

4. Is other maintenance/repair necessary?

5. Is current status/condition of vegetative cover satisfactory?

6. Rationale for field conclusions: Observations indicate cover is, in sood conditas. Eurdence of rabbits entering site under mesh.

\section{E. CERTIFICATION}

I have conducted an inspection of the Cactus Spring Waste Trenches, CAU 426, at the TTR in accordance with the Post-Closure Monitoring Plan (see Closure Report) as recorded on this checklist, attached sheets, field notes, photo logs, and photographs.

$$
D_{a i n} S \sqrt{2} \quad \text { Damiel } S . \text { Tobiadon }
$$


ATTACHMENT B

FIELD NOTES 


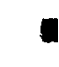

THIS PAGE INTENTIONALLY LEFT BLANK

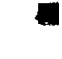


4 TITLE

Work continued from Page 3
PROJECT NO.

BOOK NO.

The Fot-Ciosure Inspections Cactus Springeidate Trenines Cte

Monding Jane 16,2000

elese, weren

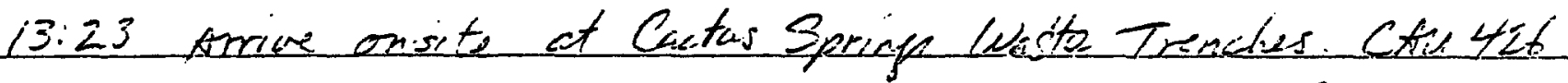

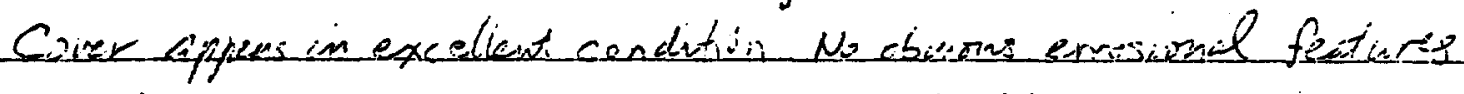

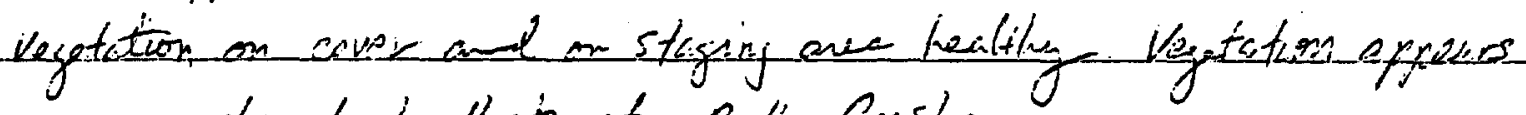
move abundeint fling at Rolier Corster.

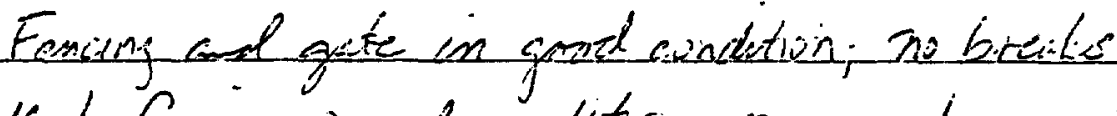

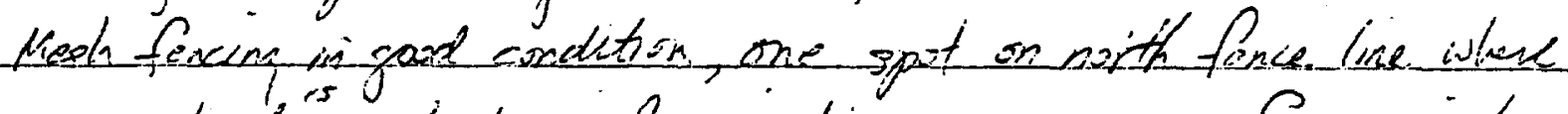

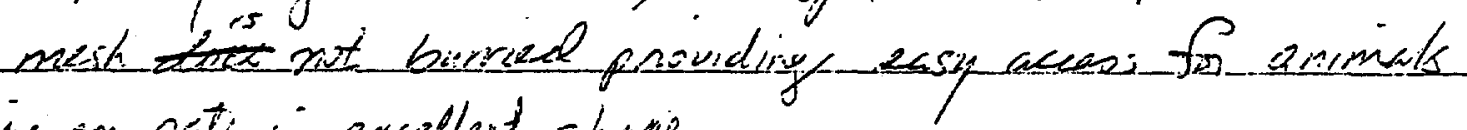

- Sugir on gati in excellend shape.

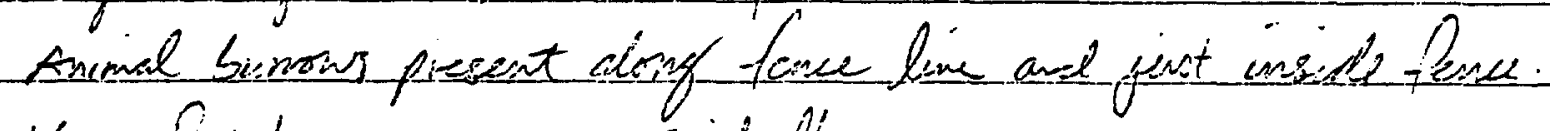
Verin few bundus on cower itself

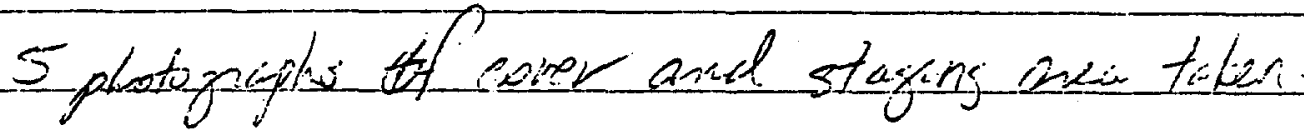

stz completcel site rspection, deferi site

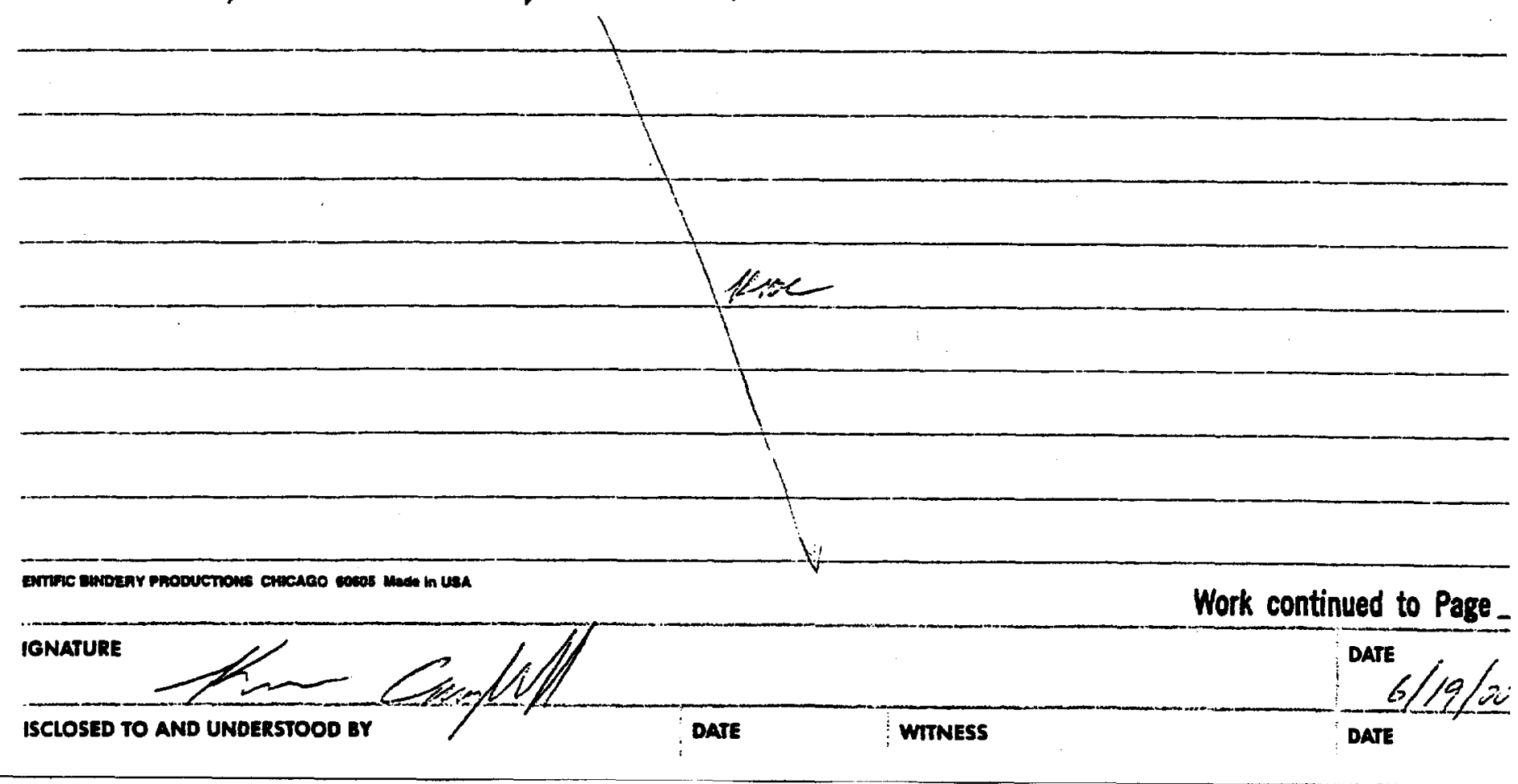




\section{TITLE}

\section{PROJECT NO.}

Work continued from Page 35

BOOK NO.

TRE POST- UOSWRE INZSEECTONT-CONTNUES

LESAY NQWEMGEK ZL, 2300

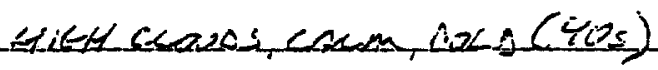

DISO INZFECTION OE CACTUS SARNAE WDATE TEENOHES.

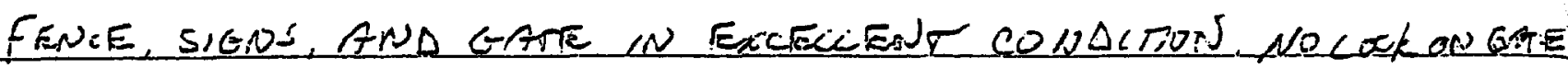

EVILENCE OF SMPRC ANIMEL; SERMTHNG UNDER

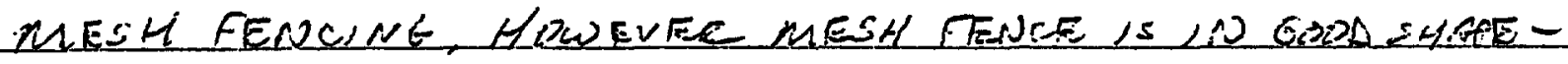

NO DAMEGTE NeTES: MIPOR BUREeWISE NeTRA

INSICE FRQNCE LINE.

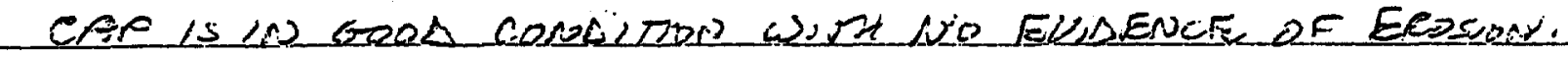

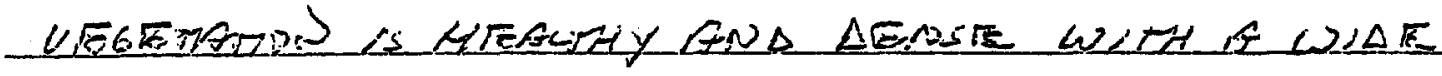

WARIEIY OF SHIVAS AND GEASE.

15 COMfLETEA CFCTUS SERING INSFECTIDN

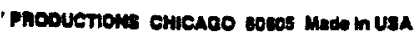

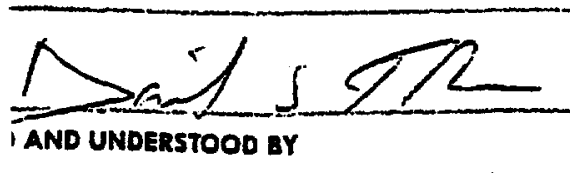

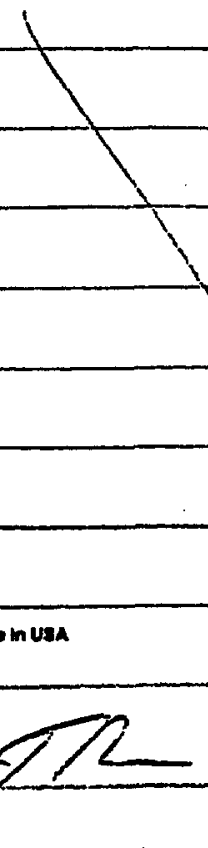

Work continued to Page $\leq \neq$

$\frac{i / 21 / 00}{\text { DATE }}$ 
ATTACHMENT C

\section{PHOTOGRAPH LOG AND PHOTOGRAPHS}




\section{PHOTOGRAPH LOG}

\begin{tabular}{|c|c|l||}
\hline $\begin{array}{c}\text { PHOTO } \\
\text { NUMBER }\end{array}$ & DATE & \multicolumn{1}{c||}{ DESCRIPTION } \\
\hline 1 & $5 / 24 / 2000$ & $\begin{array}{l}\text { View of the cover looking northeast. Vegetation is healthy but } \\
\text { sparse compared to native areas outside fenced area. }\end{array}$ \\
\hline 2 & $5 / 24 / 2000$ & View of the staging area taken from entrance gate looking east. \\
\hline 3 & $6 / 19 / 2000$ & View to the east from outside gate. \\
\hline 4 & $6 / 19 / 2000$ & View to the north of the cover. \\
\hline 5 & $11 / 14 / 2000$ & View to the east of staging area and cover. \\
\hline 6 & $11 / 14 / 2000$ & View to the north of cover. Vegetation sparse but healthy. \\
\hline 7 & $11 / 21 / 2000$ & View to the east from gate. \\
\hline 8 & $11 / 21 / 2000$ & View to the southwest of cover. \\
\hline
\end{tabular}




\section{a}

^

$\square$

a

$\square$ 







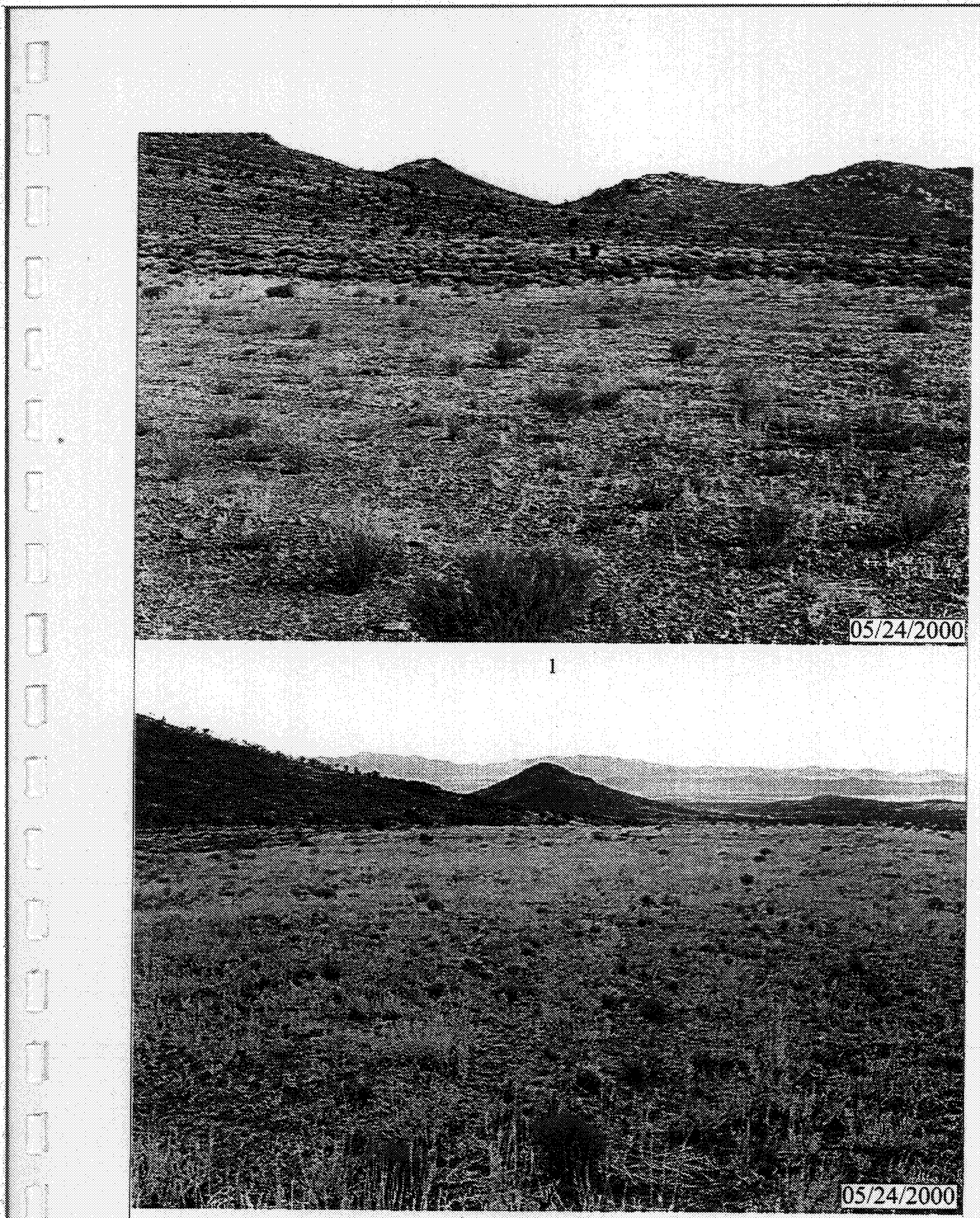




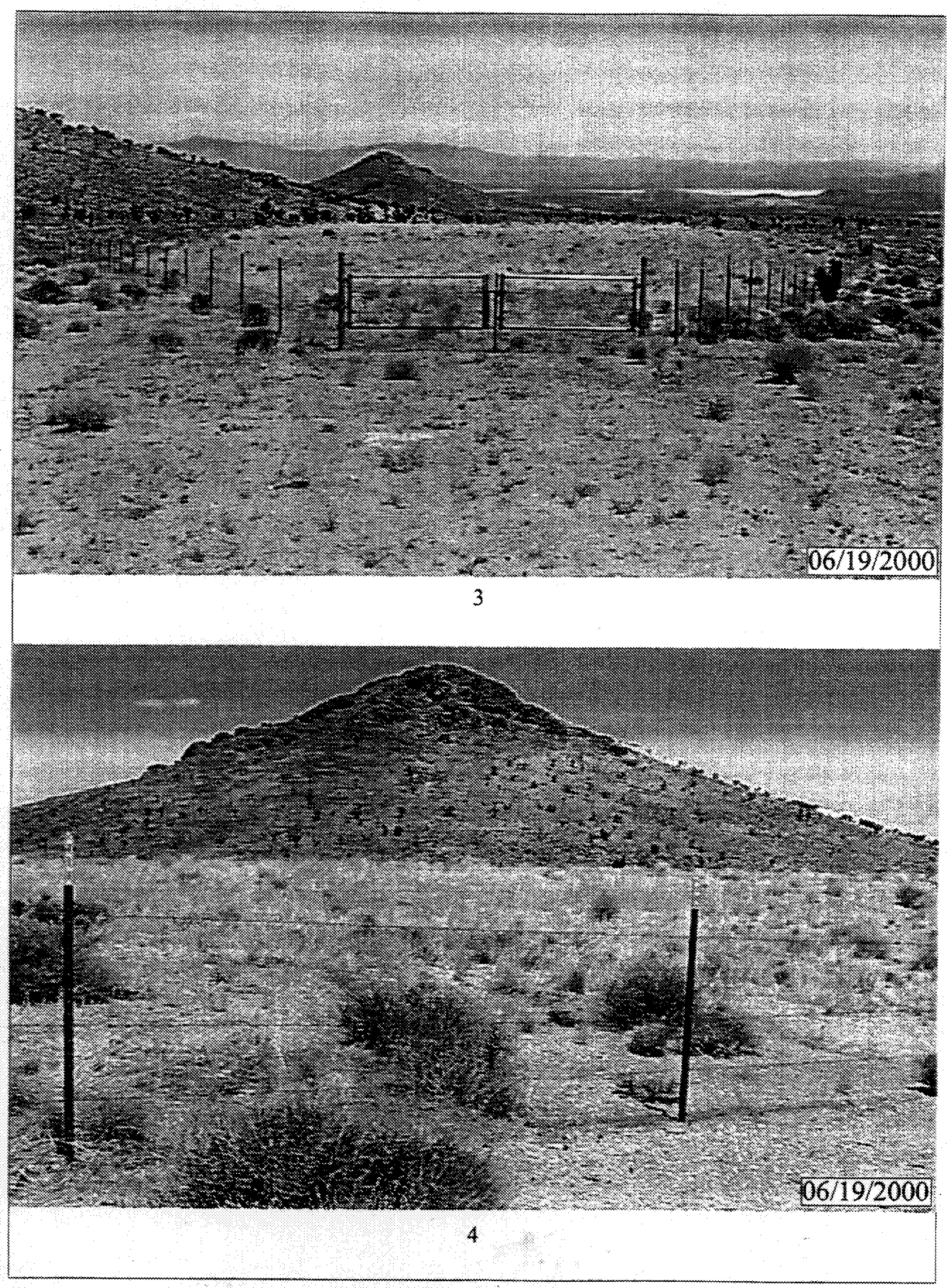




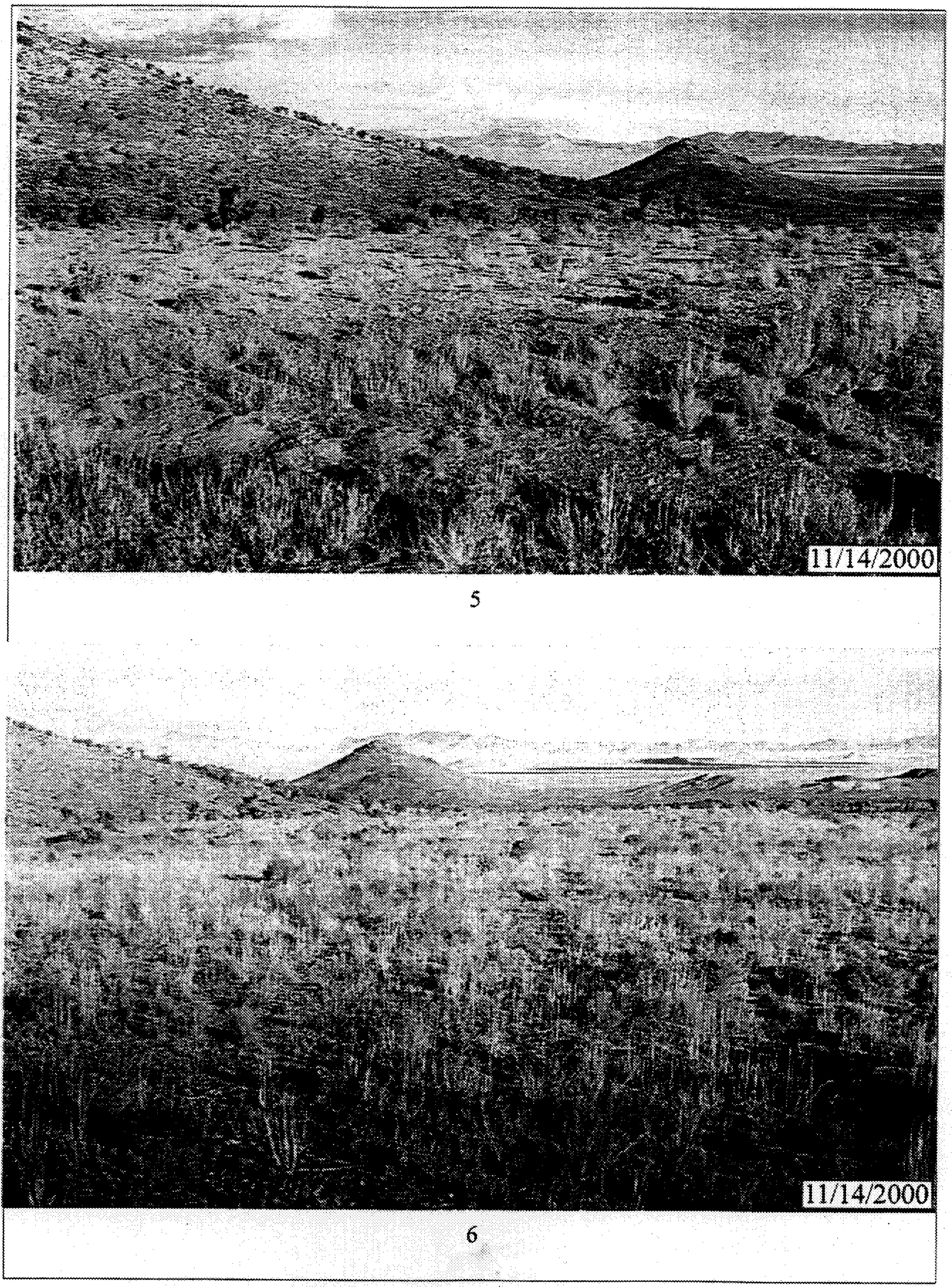




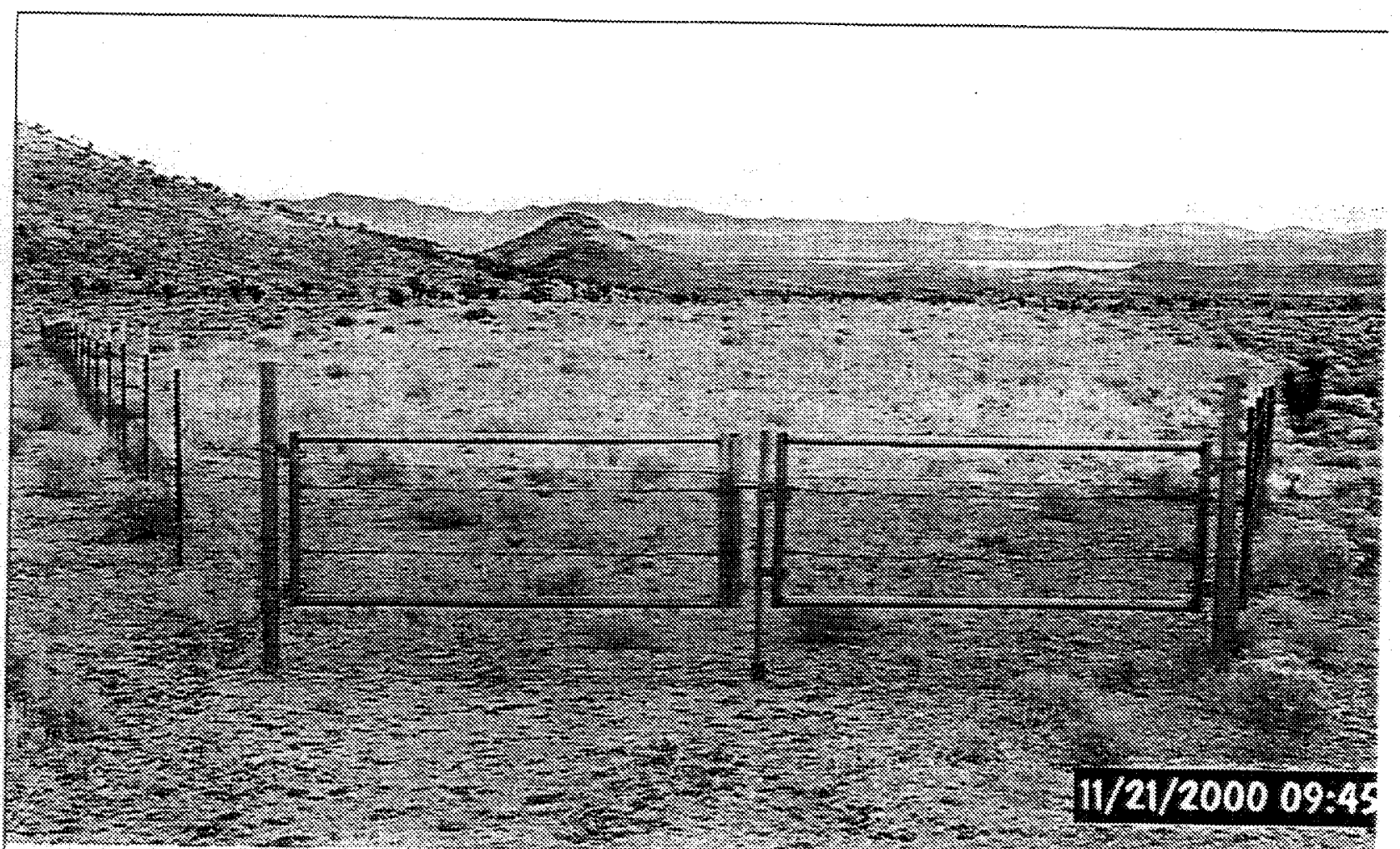
7

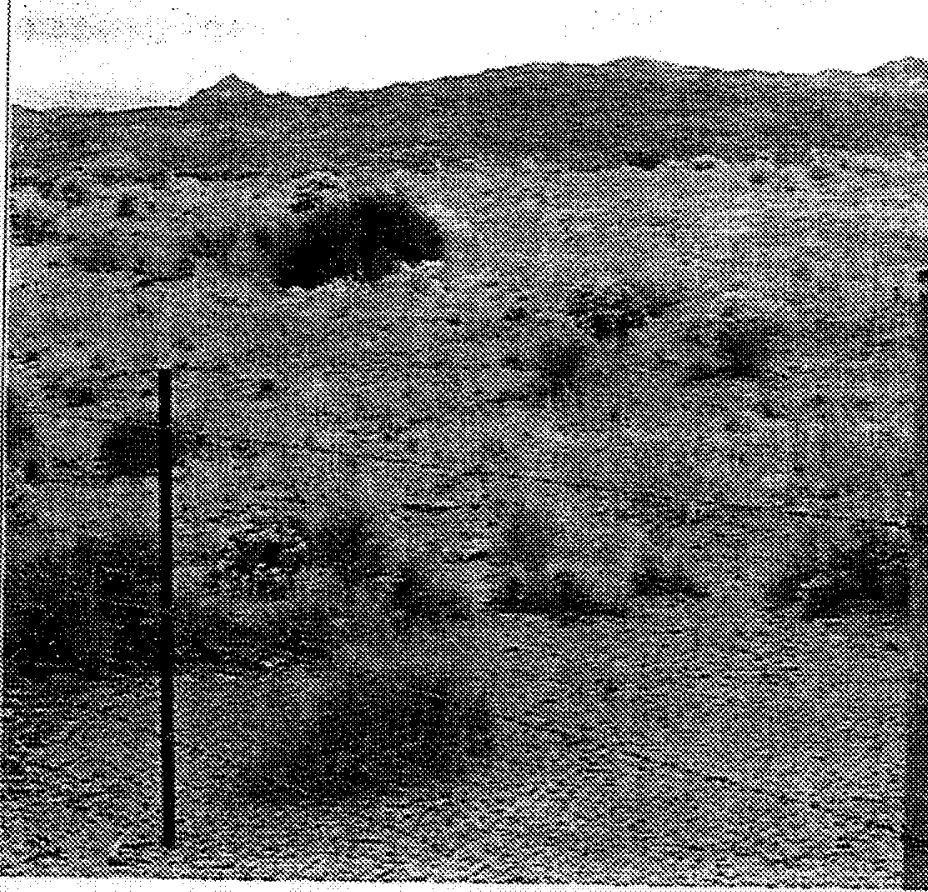




\section{DISTRIBUTION LIST}

*Provide copy of initial distribution of Revision 0; remainder of list gets Revision 0 if approved without changes. The entire list receives Revision 1 , if issued.

\section{Nevada Department of Environmental Protection}

Paul Liebendorfer

Bureau of Federal Facilities

Division of Environmental Protection

333 W. Nye Lane, Room 13B

Carson City, NV 89706-0866

Mike McKinnon, Las Vegas Office

Bureau of Federal Facilities

Division of Environmental Protection

555 E. Washington, Suite 4300

Las Vegas, NV 89010-1043
2 (Controlled)*

1 (Controlled)* $^{*}$

\section{U.S. Department of Energy}

Janet Appenzeller-Wing

1 (Uncontrolled)*

Environmental Restoration Division

U.S. Department of Energy

National Nuclear Security Administration

Nevada Operations Office

P.O. Box $98518 \mathrm{M} / \mathrm{S} 505$

Las Vegas, NV 89193-8518

Kevin Cabble

1 (Uncontrolled)*

Environmental Restoration Division

U.S. Department of Energy

National Nuclear Security Administration

Nevada Operations Office

P.O. Box $98518 \mathrm{M} / \mathrm{S} 505$

Las Vegas, NV 89193-8518

Sabrina Lawrence

Environmental Restoration Division

1 (Controlled)* $^{*}$

U.S. Department of Energy

National Nuclear Security Administration

Nevada Operations Office

P.O. Box $98518 \mathrm{M} / \mathrm{S} 505$

Las Vegas, NV 89193-8518 


\section{U.S. Department of Energy (continued)}

U.S. Department of Energy

1 (Uncontrolled, Office of Scientific and Technical Information electronic copy

175 Oak Ridge Turnpike

P.O. Box 62

Oak Ridge, TN 37831-0062

Manager, Southern Nevada

1 (Controlled \&

FFACO Public Reading Room

1 Uncontrolled)

P.O. Box $98521 \mathrm{M} / \mathrm{S}$ NLV040

Las Vegas, NV 89193-8521

Manager, Northern Nevada

1 (Uncontrolled)

FFACO Public Reading Room

Nevada State Library and Archives Federal Publications

100 North Stewart Street

Carson City, NV 89701-4285

Technical Information Resource Center

1 (Uncontrolled)

U.S. Department of Energy

National Nuclear Security Administration

Nevada Operations Office

P.O. Box $98521 \mathrm{M} / \mathrm{S} 505$

Las Vegas, NV 89193-8521

\section{Bechtel Nevada}

Correspondence Control

1 (Uncontrolled)*

Bechtel Nevada

P.O. Box $98521 \mathrm{M} / \mathrm{S}$ NLV008

Las Vegas, NV 89193-8521

Environmental Management Library

1 (Uncontrolled)*

Bechtel Nevada

P.O. Box 98521 N/S NLV080

Las Vegas, NV 89193-8521

Kevin Campbell

1 (Uncontrolled)*

Bechtel Nevada

P.O. Box $98521 \mathrm{M} / \mathrm{S}$ NTS306

Las Vegas, NV 89193-8521 


\section{DISTRIBUTION LIST (Continued)}

\section{Bechtel Nevada (continued)}

Ann Heidema

1 (Uncontrolled)

Bechtel Nevada

P.O. Box $98521 \mathrm{M} / \mathrm{S}$ NLV022

Las Vegas, NV 89193-8521

Ronald Jackson

1 (Uncontrolled)*

Bechtel Nevada

P.O. Box $98521 \mathrm{M} / \mathrm{S}$ NTS306

Las Vegas, NV 89193-8521

Wayne Johnson

1 (Uncontrolled)*

Bechtel Nevada

P.O. Box $98521 \mathrm{M} / \mathrm{S}$ NTS306

Las Vegas, NV 89193-8521

Steve Nacht

1 (Uncontrolled)*

Bechtel Nevada

P.O. Box $98521 \mathrm{M} / \mathrm{S}$ NTS306

Las Vegas, NV 89193-8521

\section{IT Corporation}

Lynn Kidman

1 (Uncontrolled)*

IT Corporation

P.O. Box 93838 M/S 439

Las Vegas, NV 89193-8521

IT FFACO Support Office

1 (Controlled)

IT Corporation

P.O. Box 93838 M/S 439

Las Vegas, NV 89193-8521 